\title{
Ayrılık anksiyetesi bozukluğu ile ilişkili okul reddi; Bir ergen olgu sunumu
}

\section{School refusal associated with separation anxiety disorder; an adolescent case report}

\author{
Mustafa Yasin Irmak ${ }^{1}$, Ayşe Irmak ${ }^{2}$, Duygu Murat ${ }^{3}$, Nagehan Üçok Demir ${ }^{4}$
}

1 Çocuk ve Ergen Ruh Sağlığı ve Hastalıkları, Kasımpaşa Asker Hastanesi, i̇stanbul, Türkiye.

2 Çocuk ve Ergen Ruh Sağlığı ve Hastalıkları ABD, Erciyes Üniversitesi Tıp Fakültesi, Kayseri, Türkiye.

3 Çocuk ve Ergen Ruh Sağlığı ve Hastalıkları, Van Devlet Hastanesi, Van, Türkiye.

4 Çocuk ve Ergen Ruh Sağlığı ve Hastalıkları, Niğde Devlet Hastanesi, Niğde, Türkiye

Yazında, ayrılık anksiyetesi bozukluğu $(A A B)$ ve okul reddi ile ilgili çok sayıda çalışma bulunmaktadır. Bu çalışmalardaki olguların genellikle çocuk yaşta olduğu bilinmektedir. Biz bu yazıda okul reddi şikayeti ile kliniğimize başvuran ancak okula gitmek istememesinin altında $A A B$ tespit edilen bir ergen olguya dikkat çekmeyi amaçladık.

Anahtar Kelimeler: ergen, ayrılık anksiyetesi bozukluğu, okul reddi
In literature, there are lots of studies about separation anxiety disorder (SAD) and school refusal. Of the patients in these studies, it is generally known to child age group. In this paper, we aimed to draw attention to an adolescent patient with SAD who admitted to our clinic with complaint of school refusal and there is SAD under his unwillingness to go to school.

Keywords: adolescent, separation anxiety disorder, school refusal 


\section{Giriş}

Ayrllık anksiyetesi bozukluğu (AAB), kişinin temel bağlanma figüründen veya evinden ayrı kalmaya karşı gösterdiği, aşırı korku ve kaygı ile kendini gösteren bir psikiyatrik bozukluktur.1 Hayatın ilk yılında ortaya çıkan normal çocuk gelişiminin bir parçası olan ayrılık kaygısı ise bir çocuğun temel bağlanma figüründen ayrılmaya gösterdiği bir tepkidir.2 Çocuğun 18-24 aylarında nesne sürekliliğin gelişimiyle ayrılık kaygısı azalır.3 $A A B$ ise kişinin, gelişim düzeyi ile uyumlu olmayan şekilde ayrılık kaygısına sahip olmasıdır. $A A B^{\prime} l i$ bireyler, kendisine veya temel bağlanma figürüne zarar geleceğini ve bu sebeple tekrar birleşemeyeceklerini düşünürler. DSM-5'e göre $A A B$ tanısı alabilmesi için bu durumun çocuklarda en az 4 haftadır, yetişkinlerde ise en az 6 aydır devam ediyor olması gerekmektedir.1

Klinisyenler, AAB'li çocuklara sıklıkla çocukların temel bağlanma figürlerinden ilk kez ayrı kaldıkları okula başlangıç zamanlarında rastlamaktadır.4 Ergenlik yaş grubunda ise klinisyen tarafından $A A B$ belirtileri gözden kaçabilmektedir. $A A B$, uygun tedavi edilmediğinde kişinin yaşamını olumsuz etkilemektedir. Biz bu yazıda belirtileri ilk kez ergenlik çağında ortaya çıkan AAB'li bir ergen olguyu sunmayı amaçladık.

\section{OLGU}

A, 14 yaşında erkek çocuğu, iki kardeşin en büyüğü, anne, baba ve kardeşi ile birlikte yaşıyordu. Kliniğimize sınavlarında başarılı olduğu yatılı eğitim okuluna gitmek istememe ve okula gitmeyi reddetme şikayeti ile ebeveynleri tarafından getirildi. Oturdukları ev kendilerine aitti ve olgunun doğumundan itibaren bu evde yaşadığı öğrenildi. A'nın ruhsal durum muayenesinde görüşmeye istekli olduğu, soruları amacına uygun cevapladığı ve görüşmeci ile iletişime açık olduğu gözlendi.
Duygudurumu kaygılı olup duygulanımı duygudurumu ile uyumluydu. Düşünce içeriğinde evden ayrı kalma ile ilgili yoğun kaygılı düşünceler mevcuttu. Olgunun daha önce psikiyatrik başvurusu ve kronik bir hastalığının olmadığı öğrenildi. Ebeveynlerinin özgeçmişinde herhangi bir psikiyatrik hastalık, kronik hastalık, geçirilmiş ciddi bir hastalık ve kaza öyküsü yoktu. Olgunun daha önce örgün eğitim aldığı okula gitmek hususunda herhangi bir isteksizlik göstermediği, kazandığı yatılı eğitim okuluna gitmediği, ebeveynlerinin gitmesi için ısrar etmeleri üzerine sık sık ağladığı ve hırçınlaştığı öğrenildi. Olgunun yakın akraba ve arkadaşlarında ebeveynlerinden birisi yanında olmadan kalamadığı, gecenin ilerleyen vakitlerinde ebeveynlerinden gelip kendisini almasını istediği öğrenildi. Olgumuz kendisinin bu durumu aşmak için çabaladığını ancak başarısız olduğunu, yatılı eğitim veren okula gitmek istediğini ancak geceleri orada geçirmek istemediğini ifade ediyordu. Geceleri ebeveynlerinden uzakta kaldığında kendini sıkıntıda hissettiği, ebeveynlerine ulaşması gerektiği ve tekrar onlara kavuşamama hakkında düşüncelerin kendisini meşgul ettiği, bu durumlarda sebepsiz yere karın ağrılarının olduğu öğrenildi. Hayatının diğer alanlarında aşırı kaygııı olmadığı, örgün eğitim veren okula tek başına gidip gelebildiği, arkadaşları ile faaliyetlere tek başına katılabildiği, gün içi şehir dışı gezilere tek başına çıkabildiği öğrenildi. Yapılan psikiyatrik görüşme ve değerlendirmeler sonucu DSM-5 kriterlerine göre $A A B$ tanısı düşünülerek olguya sertralin

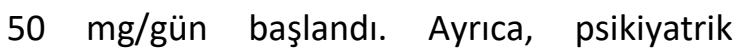
değerlendirmede $A A B^{\prime} y e$ eşlik eden bir psikiyatrik bozukluğa rastlanmadı. Daha sonra randevularına gelmeyen hastaya dört yıl sonra ulaşıldı. Dört yıl sonra yapılan ruhsal değerlendirilmesinde ilk başvuru şikâyetlerinin olmadığı, tedavisine kendisinin yaklaşık bir yıl devam ettiği, okulun ilk yılında başvuru 
şikâyetleri nedeniyle okulu bırakma noktasına geldiği ancak şu an akademik ve sosyal hayatı için bulunduğu yatılı eğitim veren okula devam ettiği için bu durumdan memnun olduğu öğrenildi.

\section{TARTIŞMA}

Olgunun ebeveynlerinden ve evinden ayrı kalamama, ayrı kalma ihtimalinin olduğu yatılı okula başlamada isteksizliği, okula gitmeyi reddetmesi, somatik yakınmalarının olması ve bu durumun 4 haftayı aşan süredir devam etmesi $A A B$ tanısı koymamızı kolaylaştırmıştır. $A A B, D S M-I V$ 'de sadece çocukluk çağında görülen bir bozukluk olarak tanımlanırken, DSM-5'te anksiyete bozuklukları içinde tanımlanmış ve erişkinlik çağı tanı kriterleri eklenmiştir.1 DSM-5'te AAB'nin çok nadiren ergenlik çağında başladığı bildirilmektedir.1 Okul öncesi veya okul çağındaki çocuklarda sık görülmesi ergenlik çağında başlangıç gösteren $A A B$ 'nin gözden kaçmasına neden olabilir.

Okul reddi şikayeti olan çocuk ve ergenlerin klinik özelliklerinin araştırıldığı bir çalışmada çocukların \%74.5'nin $A A B$ tanısı aldığı belirtilmiştir.5 Çalışmada $A A B$ tanısı alan çocukların belirtileri incelendiğinde okula gitmek istememe (\%92.3) en sık görülen belirti iken, evden her ayrıldığında aşırı kaygılanma (\%89.7) ve ayrılma anlarında bedensel yakınmalar eşlik etmesi (\%87.2) diğer sık belirtiler olarak saptanmıştır.5 Benzer bir vaka-kontrol çalışmasında da okul reddi olan çocukların psikiyatrik değerlendirmeleri sonucunda çocukların en sık AAB (\%76) tanısı aldığı belirtilmiştir. 6 Okul reddinin görüldüğg̈ yaygın anksiyete bozukluğu, sosyal fobi, depresyon uyum bozukluğu, özgül fobi, karşıt olma karşıt gelme bozukluğu ve travma sonrası stres bozukluğu gibi psikiyatrik bozukluklardan ayırıcı tanısının yapılması önemlidir.1,6,7 Olgumuz da klinik başvuru şikayeti sadece okul reddi olan $A A B$ tanısı almıştır.

Türkbay ve ark.nın yaptıkları çalışmada $A A B$ tanısı alan çocuklarda en sık belirtinin okula gitmek istememe (\%75) olduğu belirtilmiştir.4 Yine yaş ortalaması $7.7 \pm 2.9$ yıl olan $166 \mathrm{AAB}^{\prime} \mathrm{li}$ çocuğun, başvuru bilgilerinin geriye dönük incelendiği geniş kapsamlı bir çalışmada ise çocukların kliniğine en sık okula gitmek istememe (\%53) ve somatik yakınmalar (\%19) ile başvurduğu belirtilmiştir.8 Yapılan çalışmalarda ergenlik çağında başvuru şikayetlerini ele alan çalışmalar az sayıdadır. Gümüştaş ve ark. yaptıkları retrospektif çalışmada okul reddi davranışı nedeniyle gelen erkeklerde bu davranışın lise döneminde başladığı ve yıkıcı davranım bozukluğu tanılarının eşlik ettiğini belirtmişlerdir.9 Olgumuzda da okul reddi davranışı şikayeti bu çalışma ile benzer olarak lise çağında başlamasına rağmen olgumuz yıkıcı davranım bozukluğu tanısı almamıştı.

$A A B$ belirtileri ergenlerde okul çağı çocuklarına göre değişik şekilde kendini göstermektedir.10 Yeni bir birey olma yolunda gelişen ergenler $A A B$ nedeniyle evden uzakta kalması gereken kamp programları, yurt dışı eğitim programları gibi etkinliklere katılmak ve yatılı okulları tercih etmek istemeyebilirler. Bu yüzden sosyal ve akademik hayatları olumsuz etkilenebilir.1 Sosyal ve akademik hayatları olumsuz etkilenir. Olgumuzda da okula gitmek istememe yakınması veya şikâyeti, okul reddinden ziyade ebeveynlerinden ayrı kalmaya karşı gösterdiği bir davranış olarak karşımıza çıkmaktadır. Ergenlerle yapılan psikiyatrik görüşmelerde bu ve benzeri durumların akılda tutulması $A A B^{\prime} l i$ ergenlerin tedaviye erken ulaşmalarına yarar sağlayacaktır. 


\section{KAYNAKLAR}

1. APA. Diagnostic and Statistical Manual of Mental Disorders. 5ed. Arlington: American Psychiatric Association; 2013.

2. Beidel DC, Turner SM. Childhood Anxiety Disorder: a guide to research and treatment. Newyork: Taylor\&Francis; 2005. p. 188.

3. Sadock BJ, Sadock VA. Kaplan and Sadock's synopsis of psychiatry: Behavioral sciences/clinical psychiatry. Lippincott Williams \& Wilkins; 2011. p.1277.

4. Türkbay T, Söhmen T. Ayrılık kaygısı bozukluğunda bireysel ve ailesel etmenler. Turk J Child Adolesc Ment Health 2001; 8: 77-84.

5. Bahalı K, Yolga Tahiroğlu A, Avcı A. Okul reddi olan çocuk ve ergenlerin klinik özellikleri. Anadolu Psikiyatri Dergisi 2009; 10: 310-317.

6. Özcan Ö, Kılıç BG, Aysev A. Okul korkusu yakınması olan çocukların ana babalarında ruhsal bozukluklar. Türk Psikiyatri Dergisi 2006; 17: 173-180.

7. Bernstein GA, Massie ED, Thuras PD, Perwien AR, Borchardt CM, Crosby RD. Somatic symptoms in anxiousdepressed school refusers. J Am Acad Child Adolesc Psychiatry 1997; 36: 661-668.

8. Çengel Kültür SE, Tiryaki A, Ünal F. Ayrilık kaygısı bozukluğu olan çocuklarda sosyodemografik ve klinik özellikler. Turk J Child Adolesc Ment Health 2003; 10: 38.

9. Gümüştaş F, Yulaf $Y$, Gökçe S. Çocuk ve ergenlerde okul reddi davranışının nedenlerinin incelenmesi. Marmara Med J 2014;27:27-31.

10. Compton SN, Nelson AH, March JS. Social phobia and separation anxiety symptoms in community and clinical samples of children and adolescents. J Am Acad Child Adolesc Psychiatry 2000; 39: 1040-1046. 